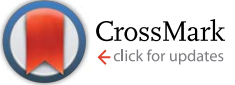

Cite this: RSC Adv., 2017, 7, 15362

\title{
Microbiome-based carboxylic acids production: from serum bottles to bioreactors $\dagger$
}

\author{
Richard Hegner, Christin Koch, * Vanessa Riechert and Falk Harnisch*
}

Microbiome-based anaerobic fermentations are promising platform technologies to convert low grade biomass into chemical building blocks. However, systematic investigations on their scalability are scarce. Here, microbiome-based production of medium-chain carboxylic acids from acetate and ethanol was systematically investigated across scales from serum bottles $(110 \mathrm{~mL})$ to standard bioreactors $(2.2 \mathrm{~L})$ in batch mode. Microbiome cultivation on serum bottle level for high throughput screening led to a considerable total medium-chain carboxylic acids concentration of $843.2 \pm 20 \mathrm{C} \mathrm{mM}$ with $77.0 \pm$ $2 \mathrm{mM} n$-butyrate and $89.2 \pm 2 \mathrm{mM} n$-caproate. Introducing agitation significantly enhanced the maximum product formation rates of $n$-butyrate $\left(r_{\mathrm{C}_{4}, \max }\right)$ and $n$-caproate $\left(r_{\mathrm{C}_{6} \text {,max }}\right)$ and was identified as a key parameter for further upscaling. The highest total medium-chain carboxylic acids concentration of $977.8 \pm 22.8 \mathrm{C} \mathrm{mM}$ with $98.5 \pm 2.1 \mathrm{mM} n$-butyrate and $97.3 \pm 2.4 \mathrm{mM} n$-caproate was reached in the $2.2 \mathrm{~L}$ standard bioreactor and was only restricted by end-product inhibition. Further, a carbon recovery of up to $94 \%$ was independent of the reactor scale proving the transferability of the microbiome and its functions. Based on cloning and sequencing the most abundant microorganisms were closest related to the model organism for microbial medium-chain carboxylic acid formation, Clostridium kluyveri. The current study demonstrates that time and resource efficient screening of functional microbiomes for relevant cultivation conditions on a small scale can be combined with its subsequent upscaling without performance loss.

Received 15th December 2016 Accepted 28th February 2017

DOI: $10.1039 / c 6 r a 28259 h$

rsc.li/rsc-advances

\section{Introduction}

A bio-based economy, i.e. bio-based fuels and chemicals, needs tailored resource management strategies. For management of the resource biomass among others anaerobic fermentation technologies based on microbiomes, i.e., open mixed microbial communities, can play a key role. ${ }^{1,2}$ Microbiome-based anaerobic fermentations, which allow upgrading low grade, i.e. nonfood, non-feed, and chemically diverse biomass to chemical building blocks, are promising platform technologies. Chemical building blocks resulting as key intermediates and products from anaerobic fermentations include hydrogen $\left(\mathrm{H}_{2}\right)$, carbon dioxide $\left(\mathrm{CO}_{2}\right)$, methane $\left(\mathrm{CH}_{4}\right)$ and medium-chain carboxylic acids (CA), i.e., $n$-carboxylic acids possessing carbon chain lengths of four $\left(\mathrm{C}_{4}\right)$ to eight $\left(\mathrm{C}_{8}\right)$ carbon atoms. ${ }^{2}$ Microbiomes themselves have already been proven to act as stable and costeffective whole cell biocatalysts in anaerobic fermentations. ${ }^{3,4}$ Due to their metabolic diversity they are able to treat complex and variable organic waste streams highly efficiently and without the need of sterilization or antibiotic treatment. ${ }^{5,6}$

Helmholtz Center for Environmental Research - UFZ, Department of Environmental Microbiology, Permoserstraße 15, 04318 Leipzig, Germany. E-mail: christin.koch@ ufz.de; falk.harnisch@ufz.de

$\dagger$ Electronic supplementary information (ESI) available. See DOI: $10.1039 / \mathrm{c} 6 \mathrm{ra} 28259 \mathrm{~h}$
However, the reactor microbiome composition and activity depends on food-webs and species interactions, and these in turn strongly depend on the substrates and intermediates available as well as on other environmental factors. ${ }^{7}$

Accordingly, for an efficient production of medium-chain CA the microbiome-based chain elongation of $n$-carboxylic acids is of particular interest. ${ }^{6,8}$ Several pathways for microbial chain elongation are described ${ }^{4}$ with the reverse $\beta$-oxidation performed by Clostridium kluyveri as model organism being most intensively studied.9-13 The reverse $\beta$-oxidation is a cyclic process comprising an oxidative and a reductive part. In the reductive part acetyl-CoA, derived from oxidation of ethanol by $\mathrm{NAD}^{+}$, is added to a CoA-activated carboxylic acid. ${ }^{4}$ This leads to a chain elongation of the acid by two carbon atoms per reaction cycle, e.g., acetic acid $\left(\mathrm{C}_{2}\right)$ is elongated to $n$-butyric acid $\left(\mathrm{C}_{4}\right)$ (eqn (1)) or $n$-butyric acid to $n$-caproic acid $\left(\mathrm{C}_{6}\right)$ (eqn (2)). In the oxidative part ATP is generated via substrate level phosphorylation while in the reductive part ATP is generated via electron-transport phosphorylation. The ratio of the substrates ethanol and acetate theoretically determines to which extend ATP is produced (substrate level phosphorylation coupled to the oxidative part vs. electron-transport phosphorylation via Rnf complex/ATP synthase coupled to the reductive part). ${ }^{6}$ In this study, like in many others (Table 1), two model substrates are used, i.e. ethanol serves as 
Table 1 Comparison of process parameters for medium-chain CA formation from the substrates ethanol and acetate using microbiomes and a pure culture of $C$. kluyveri. All listed studies were performed without medium-chain CA extraction from the fermentation broth. For studies applying complex feedstocks see review by Angenent et al. (2016)

\begin{tabular}{|c|c|c|c|c|c|c|}
\hline \multirow[b]{2}{*}{ Biocatalysts } & \multirow[b]{2}{*}{ Experimental conditions } & \multicolumn{3}{|c|}{$\begin{array}{l}\text { Max. production rate } \\
{\left[\mathrm{g} \mathrm{L}^{-1} \mathrm{~d}^{-1}\right]} \\
\text { concentration }\left[\mathrm{g} \mathrm{L}^{-1}\right] \\
(\text { concentration }[\mathrm{mM}])^{a}\end{array}$} & \multirow{2}{*}{$\begin{array}{l}\text { Total carbon bound in } \\
\text { medium-chain CA } \\
{[\mathrm{C} \mathrm{mM}]}\end{array}$} & \multirow[b]{2}{*}{ Reference } \\
\hline & & $n$-Butyrate & $n$-Caproate & n-Caprylate & & \\
\hline \multirow[t]{4}{*}{ Microbiome } & $\begin{array}{l}\text { Batch, stirred bioreactor, no } \mathrm{pH} \text { control, } \\
\text { duration: } 82 \mathrm{~h}\end{array}$ & $\begin{array}{l}6.32 \pm 0.23^{c} \\
8.68 \pm 0.18^{c} \\
(98.5 \pm 2.1)^{c}\end{array}$ & $\begin{array}{l}8.53 \pm 0.50^{c} \\
11.30 \pm 0.28^{c} \\
(97.3 \pm 2.4)^{c}\end{array}$ & - & $977.8 \pm 22.8$ & This study \\
\hline & $\begin{array}{l}\text { Fed-batch, stirred reactor, } \mathrm{pH} 7 \text {, } \\
\text { duration: } 120 \mathrm{~d}\end{array}$ & $\begin{array}{l}- \\
2.2^{c} \\
(25.0)\end{array}$ & $\begin{array}{l}0.5^{b} \\
8.2^{b} \\
(70.6)\end{array}$ & $\begin{array}{l}0.1^{b} \\
0.3^{b} \\
(2.1)\end{array}$ & 540.4 & 5 \\
\hline & $\begin{array}{l}\text { Continuous, upflow filter, pH 6.5-7.0, } \\
\text { duration: } 80 \mathrm{~d}\end{array}$ & $\begin{array}{l}- \\
2.1 \\
(23.8)\end{array}$ & $\begin{array}{l}16.6^{b} \\
11.1^{b} \\
(95.6)\end{array}$ & $\begin{array}{l}0.9^{b} \\
0.6^{b} \\
(4.2)\end{array}$ & 702.4 & 22 \\
\hline & $\begin{array}{l}\text { Continuous, upflow filter, pH 6.5-7.2, } \\
\text { duration: } 60 \mathrm{~d} \text { to } 69 \mathrm{~d}\end{array}$ & $\begin{array}{l}- \\
1.3 \\
(14.8)\end{array}$ & $\begin{array}{l}57.4^{b} \\
12.0 \\
(103.3)\end{array}$ & $\begin{array}{l}1.8^{b} \\
0.9 \\
(6.2)\end{array}$ & 728.6 & 41 \\
\hline C. kluyveri & $\begin{array}{l}\text { Batch, Hungate tubes, no } \mathrm{pH} \text { control, } \\
\text { duration: } 3 \mathrm{~d}\end{array}$ & $\begin{array}{l}- \\
2.6 \\
(30.5)\end{array}$ & $\begin{array}{l}- \\
12.8 \\
(110.2)\end{array}$ & - & 675.2 & 13 \\
\hline
\end{tabular}

electron donor as well as source of reducing equivalents and acetate as electron acceptor. , $^{\mathbf{1 4}}$

Stoichiometry: ${ }^{4}$

$$
\begin{aligned}
& \text { 6ethanol }+4 \text { acetate }^{-} \rightarrow 5 n \text {-butyrate } \\
& +\mathrm{H}^{+}+2 \mathrm{H}_{2}+4 \mathrm{H}_{2} \mathrm{O}, \Delta G_{\mathrm{r}}^{0^{\prime}}=-183.83 \mathrm{~kJ} \times 5 \mathrm{~mol}^{-1} \\
& 6 \text { 6ethanol }+5 n \text {-butyrate } \rightarrow \text { acetate }^{-}+5 n \text {-caproate }^{-}+\mathrm{H}^{+} \\
& +2 \mathrm{H}_{2}+4 \mathrm{H}_{2} \mathrm{O}, \Delta G_{\mathrm{r}}^{0^{\prime}}=-184.95 \mathrm{~kJ} \times 5 \mathrm{~mol}^{-1}
\end{aligned}
$$

Free energy change values are provided for $\mathrm{pH} 6.82$ and $37^{\circ} \mathrm{C}$.

However, the stoichiometry of the reverse $\beta$-oxidation is not fixed as suggested by eqn (1) and (2) as the absolute concentrations and ratio of ethanol and acetate and the concentration of hydrogen in the medium have a strong impact on the overall reactions ${ }^{6}$ and, thus, the yield and ratio of the produced $n$ butyrate and $n$-caproate..$^{\mathbf{9 1 2}}$

A couple of studies have been devoted to the identification and characterization of microbiomes performing mediumchain CA formation from ethanol and acetate (Table 1). However, among other factors hindering a comparative assessment these studies were exclusively performed using individual reactor setups without parallelization and only at one scale. Therefore, it remains unclear whether the performance differences in microbial chain elongation are based on differences in composition and/or activity of the exploited microbiomes or the reactor configurations and cultivation conditions used.

Small scale cultivation in serum bottles can serve as a time and resource efficient way for identifying functional microbiomes and relevant cultivation conditions with high degree of parallelization. However, the question can be raised, if the performance during serum bottle cultivation can successfully be transferred to bioreactor scale which is compatible with further upscaling to industrial scale. Therefore, we systematically investigated the microbiome-based chain elongation across scales. We demonstrate that screening of microbiome cultivation conditions in serum bottles $(110 \mathrm{~mL})$ is a time and resource efficient way for identifying a functional microbiome. Subsequently we show that upscaling from serum bottles (110 $\mathrm{mL}$ ) via $440 \mathrm{~mL}$ reactors to $2.2 \mathrm{~L}$ standard bioreactors without performance loss is feasible, demonstrating the transferability of the microbiome and its functions and identifying further relevant process parameters for respective upscaling.

\section{Material and methods}

\subsection{Inoculum, chemicals and media}

All chemicals were of at least analytical grade and were supplied from Carl Roth GmbH (Karlsruhe, Germany) and Merck KGaA (Darmstadt, Germany). Microbial media were prepared in deionized water (Millipore, Darmstadt, Germany). All experiments and sub-cultivations were carried out at $37^{\circ} \mathrm{C}$. Carrier gases and calibration gases for gas chromatography were purchased from Air Products GmbH (Berlin, Germany).

2.1.1 Screening experiments. The initial inoculum was derived from a leach-bed reactor. ${ }^{15}$ The microbiome was cultivated using sterile DSM 52 medium $\left(0.31 \mathrm{~g} \mathrm{~K}_{2} \mathrm{HPO}_{4}, 0.23 \mathrm{~g}\right.$ $\mathrm{KH}_{2} \mathrm{PO}_{4}, 0.25 \mathrm{~g} \mathrm{NH}_{4} \mathrm{Cl}, 0.20 \mathrm{~g} \mathrm{MgSO}_{4} \times 7 \mathrm{H}_{2} \mathrm{O}, 1.0$ g yeast extract, $1 \mathrm{~mL}$ of $0.1 \%(\mathrm{w} / \mathrm{v})$ Na-resazurin solution, $2.5 \mathrm{~g} \mathrm{NaHCO}_{3}, 1.0 \mathrm{~mL}$ 
seven vitamin solution, $0.25 \mathrm{~g}$ L-cystein- $\mathrm{HCl} \times \mathrm{H}_{2} \mathrm{O}, 0.25 \mathrm{~g} \mathrm{Na} \mathrm{N}_{2} \mathrm{~S}$ $\times 9 \mathrm{H}_{2} \mathrm{O}, 1 \mathrm{~mL}$ trace element solution SL-10, $1 \mathrm{~mL}$ selenitetungstate solution, dissolved in $1 \mathrm{~L}$ water, $\mathrm{pH}$ 7.8-8.0) with different concentrations of ethanol (ranging from $300 \mathrm{mM}$ to $715 \mathrm{mM}$ ) and sodium acetate (ranging from $100 \mathrm{mM}$ to 300 $\mathrm{mM}$ ). Prior to inoculation the medium was purged with a gas mixture of $80 \% \mathrm{~N}_{2}$ and $20 \% \mathrm{CO}_{2}(\mathrm{v} / \mathrm{v})$ at a rate of $250 \mathrm{~mL} \mathrm{~min} \mathrm{~m}^{-1}$ resulting in a final $\mathrm{pH}$ of 7.2 to 7.4. Further, medium according to Zhang ${ }^{16}\left(0.5 \mathrm{~g} \mathrm{NH}_{4} \mathrm{Cl}, 0.2 \mathrm{~g} \mathrm{KH}_{2} \mathrm{PO}_{4}, 0.04 \mathrm{~g} \mathrm{Na}_{2} \mathrm{SO}_{4}, 0.05 \mathrm{~g} \mathrm{KCl}\right.$, $0.01 \mathrm{~g} \mathrm{CaCl}, 0.07 \mathrm{~g} \mathrm{MgCl}_{2} \times 6 \mathrm{H}_{2} \mathrm{O}, 0.8 \mathrm{mg} \mathrm{MnCl}_{2} \times 4 \mathrm{H}_{2} \mathrm{O}$, $1.2 \mathrm{mg} \mathrm{CoCl}{ }_{2} \times 2 \mathrm{H}_{2} \mathrm{O}, 3.2 \mathrm{mg} \mathrm{FeSO}_{4} \times 7 \mathrm{H}_{2} \mathrm{O}, 0.5 \mathrm{mg} \mathrm{AlCl}_{3}$, $0.1 \mathrm{mg} \mathrm{NaMO}_{4} \times 2 \mathrm{H}_{2} \mathrm{O}, 0.2 \mathrm{mg} \mathrm{H}_{3} \mathrm{BO}_{3}, 0.5 \mathrm{mg} \mathrm{NiCl} \mathrm{N}_{2} \times 6 \mathrm{H}_{2} \mathrm{O}$, $1.1 \mathrm{mg} \mathrm{CuCl} \mathrm{Cu}_{2} \times 2 \mathrm{H}_{2} \mathrm{O}, 3.2 \mathrm{mg} \mathrm{ZnSO}_{4} \times 2 \mathrm{H}_{2} \mathrm{O}, 3 \mathrm{mg} \operatorname{EDTA}\left(\mathrm{Na}^{+}\right)$, dissolved in $1 \mathrm{~L}$ water, $\mathrm{pH}$ 6.8-6.9) was tested.

2.1.2 Microbiome maintenance. For maintenance experiments the microbiome was sub-cultivated once per $14 \mathrm{~d}$ in DSM 52 medium as described above in serum bottles $(250 \mathrm{~mL})$ with a final working volume of $110 \mathrm{~mL}$, supplemented with $300 \mathrm{mM}$ ethanol and $250 \mathrm{mM}$ sodium acetate.

2.1.3 Upscaling experiments. Upscaling experiments were performed in DSM 52 medium supplemented with $330 \pm 30 \mathrm{mM}$ ethanol and $300 \pm 30 \mathrm{mM}$ sodium acetate. A 5 day-old microbiome (see Microbiome maintenance) in the growth phase was used and inoculated to an optical density $\left(\mathrm{OD}_{600 \mathrm{~nm}}\right)$ of 0.1 .

\subsection{Reactor setup and operation}

Three different scales of reaction vessels allowing different degree of process monitoring were investigated (Table 2). Serum bottles $(250 \mathrm{~mL})$ with a final working volume of $110 \mathrm{~mL}$ were the smallest scale, without agitation but the bottles were shaken once a day. The medium was poured into the serum bottles in an anaerobic glove box. Ethanol and sodium acetate were added from sterile anoxic stock solutions followed by gas purging of the medium with a $\mathrm{N}_{2} / \mathrm{CO}_{2}$ mixture as stated above. The same procedure was applied to the tailor-made lab flasks $(600 \mathrm{~mL})$ with a final working volume of $440 \mathrm{~mL}$. Here stirring was performed with a magnetic stir bar $(150 \mathrm{rpm})$. For the third scale the liquid medium in standard bioreactors $\left(3 \mathrm{~L}\right.$, UniVessel ${ }^{\circledR}$ double-walled glass culture vessel, Sartorius, Goettingen, Germany) was made anoxic by first purging with $\mathrm{N}_{2}$ till no dissolved oxygen was measured (VisiFerm DO 225, Hamilton, Switzerland) followed by switching to $\mathrm{N}_{2} / \mathrm{CO}_{2}$ mixture. In this context "standard bioreactor" refers to the standard setup of a conventional commercially available bioreactor with defined and reproducible operation parameters (e.g. cylindrical reactor geometry, agitators, gas sparger, gas outlet, sampling port, removable reactor lid etc.). The final working volume was $2.2 \mathrm{~L}$ and stirring was applied by a disk-type six-blade impeller (from reactor top, $150 \mathrm{rpm}$ ). On all scales the growth of the microbiome was monitored by measuring the $\mathrm{OD}_{600 \mathrm{~nm}}(1.5 \mathrm{~mL}$ semimicro cuvettes, UviLine 9400 spectrophotometer, Mainz, Germany). Furthermore, liquid samples $(1 \mathrm{~mL})$ for HPLC and GCMS analysis were taken regularly and centrifuged $(15000 \times g$, $15 \mathrm{~min}, 4{ }^{\circ} \mathrm{C}$ ). For the serum bottles and the lab flasks the $\mathrm{pH}$ was determined offline with a $\mathrm{pH}$ meter $\left(\mathrm{H} 138\right.$ miniLab $^{\mathrm{TM}}$ Elite (HACH-Lange, Germany)) which was calibrated on a daily basis.
The $\mathrm{pH}$ of the fermentation broth in the standard bioreactors was measured online in situ with a pH probe (EasyFerm VP Plus 225, Hamilton, Switzerland). All experiments were performed without $\mathrm{pH}$ control.

\subsection{Analytical methods}

2.3.1 Liquid phase analysis by HPLC. HPLC (Shimadzu Scientific Instruments, USA) measurements of the aqueous liquid phase were performed with a refractive index detector (RID-10A) using a Hi-Plex H column $(300 \mathrm{~mm} \times 7.7 \mathrm{~mm} \mathrm{ID,} 8$ $\mu \mathrm{m}$ pore size, Agilent Technologies, Germany) at $50{ }^{\circ} \mathrm{C}$ being eluted with $5 \mathrm{mM} \mathrm{H}_{2} \mathrm{SO}_{4}$ at $0.5 \mathrm{~mL} \mathrm{~min}^{-1}$ for $75 \mathrm{~min}^{-1}$. Peak identification and calibration was carried out with external standards (calibrated substances: ethanol, acetate, $n$-butyrate and $n$-caproate with four point calibration, HPLC calibration limit for $n$-butyrate and $n$-caproate is $0.1 \mathrm{mM} ; R^{2}=0.99$; propanol, butanol, pentanol, formate, propionate, $n$-valerate, and $n$ heptanoate with three point calibration; $R^{2}=0.99$ ).

2.3.2 Liquid phase analysis by GC-MS. For verifying the HPLC results, selected liquid samples were also analyzed by a GC-MS system (gas chromatograph 7890A including a mass spectrometer $5975 \mathrm{C}$ inert MSD with triple axis detector, Agilent Technologies, USA). A sample volume of $0.5 \mu \mathrm{L}$ was injected (split ratio of $1: 20$, inlet temperature $220^{\circ} \mathrm{C}$, helium as carrier gas with a constant flow of $1.2 \mathrm{~mL} \mathrm{~min}^{-1}$ ) into a ZB-WAX plus capillary column ( $30 \mathrm{~m} ; 0.25 \mathrm{~mm} ; 0.25 \mu \mathrm{m}$, Phenomenex, USA). The column temperature program was set $2 \mathrm{~min}$ at $50{ }^{\circ} \mathrm{C}$ followed by a heating rate of $15{ }^{\circ} \mathrm{C} \min ^{-1}$ to $250{ }^{\circ} \mathrm{C}$. The temperature of the transfer line to the $\mathrm{MS}$ was $240{ }^{\circ} \mathrm{C}$ and the electron impact ionization source was set to $230{ }^{\circ} \mathrm{C}$, the MS quadrupole to $150{ }^{\circ} \mathrm{C}$. For stabilization retention time locking (RTL) was used. Mass scanning was performed in the range of $\mathrm{m} / \mathrm{z} 18-300$. Each peak was identified by library (NIST 2014 Mass Spectral Library, NIST, USA) and standard substance based comparison. The internal standard used was propionic acid. Calibrated substances were ethanol, acetate, $n$-butyrate, $n$-valerate, $n$-caproate, $n$-heptanoate and $n$-caprylate with four point calibration $\left(R^{2} \geq 0.99\right.$; calibration limits: ethanol: $2.0 \mathrm{mM}$; acetate: $1.5 \mathrm{mM}$; $n$-butyrate: $0.4 \mathrm{mM}$; $n$-valerate: $0.4 \mathrm{mM}$; $n$-caproate: $0.3 \mathrm{mM}$; $n$ heptanoate: $0.015 \mathrm{mM}$; $n$-caprylate: $0.014 \mathrm{mM}$ ).

2.3.3 Gas phase analysis. Produced gas was collected in gas bags (barrier material: aluminium compound foil (Hermann Nawrot AG, Wipperfuerth, Germany)) and regularly analyzed $\left(\mathrm{H}_{2}, \mathrm{~N}_{2}, \mathrm{O}_{2}, \mathrm{CO}_{2}\right.$, and $\left.\mathrm{CH}_{4}\right)$ with a four channel 3000 Micro GC Gas Analyzer (INFICON, Colongne, Germany) (for details see ESI and Table $\mathrm{S} 1 \dagger)$.

2.3.4 Community composition. For analyzing the community composition terminal restriction fragment length polymorphisms (T-RFLP) analysis as well as cloning and sequencing were performed for selected samples according to standard procedures. ${ }^{17}$ In short, DNA was extracted with the NucleoSpin ${ }^{\circledR}$ Tissue kit (Macherey-Nagel, Germany) and the 16S ribosomal RNA gene used for amplification (primer set UniBac27F (FAM labeled for T-RFLP, 5'-AGAGTTTGATCMTGGCTCAG-3') and 1492r ( $5^{\prime}$-TACGGYTACCTTGTTACGACTT-3'), supplied by MWG Biotech, resulting in a PCR product of about $1500 \mathrm{bp}$ ). T-RFLP 
Table 2 Kinetic and process parameters for the medium-chain $C A$ ( $n$-butyrate $\left(C_{4}\right)$ and $n$-caproate $\left(C_{6}\right)$ ) production on the different volumetric scales. The variability of values is given as standard deviation

Reactor type

Number of replicates

Reaction volume

Reactor volume

Run time [h]

Agitation

Reynolds number

Headspace volume

Working volume/headspace ratio

Ethanol/acetate ratio

Substrate $[\mathrm{mM}]$

Carbon provided [C mM]

Products [mM]

Carbon recovered in $\mathrm{C}_{4}$ and $\mathrm{C}_{6}[\mathrm{C} \mathrm{mM}]$

Substrate carbon remaining [C $\mathrm{mM}]$

Carbon consumed [C mM]

$\mu_{\max }{ }^{b}\left[\mathrm{~h}^{-1}\right]$

$\mathrm{C}$ recovery [\%]

Max. medium-chain CA formation

rate $r_{\mathrm{x}, \max }{ }^{b}\left[\mathrm{mmol} \mathrm{L}^{-1} \mathrm{~h}^{-1}\right]$

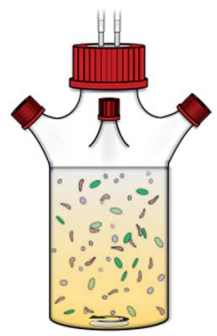

Tailor-made lab flask

4

$440 \mathrm{~mL}$

$110 \mathrm{~mL}$

$250 \mathrm{~mL}$

85

No (shaking once a day)

$140 \mathrm{~mL}$

2.3

1.2

Ethanol: $305 \pm 8$

Acetate: $252 \pm 8$

$1104 \pm 57$

$\mathrm{C}_{4}: 77.0 \pm 2.0$

$\mathrm{C}_{6}: 89.2 \pm 2.0$

$811 \pm 21$

$384 \pm 29$

$727 \pm 70$

$0.041 \pm 0.004$

$94.06 \pm 7.74$

$\mathrm{C}_{4}: 1.94 \pm 0.05$

$\mathrm{C}_{6}: 2.27 \pm 0.06$

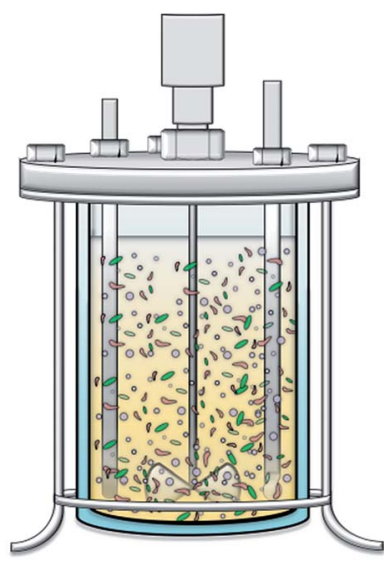

Standard bioreactor

3

$2.2 \mathrm{~L}$

$3.0 \mathrm{~L}$

82

Yes (disk-type six-blade impeller, $150 \mathrm{rpm})$

$9.4 \times 10^{3}$

$1.6 \mathrm{~L}^{a}$

1.4

1.1

Ethanol: $322 \pm 3$

Acetate: $300 \pm 2$

$1245 \pm 5$

$\mathrm{C}_{4}: 98.5 \pm 2.1$

$\mathrm{C}_{6}: 97.3 \pm 2.4$

$921 \pm 33$

$353 \pm 28$

$892 \pm 26$

$0.059 \pm 0.000$

$92.87 \pm 5.66$

$\mathrm{C}_{4}: 2.99 \pm 0.11$

$\mathrm{C}_{6}: 3.06 \pm 0.08$

${ }^{a}$ Includes the volume of the gas bag which was constantly connected to the reactor vessels. ${ }^{b}$ Calculation based on three independent biological replicates $(n=3)$ as only for three replicates on each scale the sampling frequency was dense enough to accurately calculate the respective number.

analysis was based on restriction digestion with the restriction endonucleases HaeIII and RsaI and subsequent analysis using an ABI PRISM Genetic Analyzer 3130xl (Applied Biosystems, Darmstadt, Germany). Terminal restriction fragments (tRFs) with a contribution to the total peak area of more than $1 \%$ were included in the analysis. A clone library based on a representative bioreactor sample and consisting of 167 clones was investigated. Partial sequencing of these clones was then performed with M13 primers, followed by UniBac27F and Univ519r ( $5^{\prime}-$ GWATTACCGCGGCKGCTG-3'). Sequencing was performed with Sanger sequencing and resulted in fragments of about $500 \mathrm{bp}$ length. The phylogenetic affiliation of the sequences was analyzed using the RDP classifier ${ }^{18}$ and BLAST. ${ }^{19}$ All sequences were deposited in the GenBank database under accession numbers KX422636 to KX422802.
2.3.5 Cell dry weight. Cell dry weight was determined for two independent runs on bioreactor scale after $82 \mathrm{~h} .10 \mathrm{~mL}$ cell suspensions were taken and centrifuged for $30 \mathrm{~min}(10000 \times g$, $4{ }^{\circ} \mathrm{C}$ ). Subsequently, the supernatant was removed and the cells were washed in $5 \mathrm{~mL} 7.8 \mathrm{mM}$ phosphate buffer. This was followed by a second centrifugation and washing step. After the final centrifugation step the supernatant was discarded and the cell pellets were dried at $65{ }^{\circ} \mathrm{C}$ for at least $48 \mathrm{~h}$ until constant weight was reached.

2.3.6 CHNS analysis of yeast extract. The composition (ratio of $\mathrm{C}: \mathrm{H}: \mathrm{O}: \mathrm{N}$ ) of the yeast extract (Merck KGaA (Darmstadt, Germany)) that was used in the experiments was determined using CHNS analysis according to DIN EN ISO 16948:2015 with a VarioMacroCube macro analyzer (Elementar, Langenselbold, Germany). Oxygen was determined indirectly by mass difference calculation. 


\subsection{Calculations}

2.4.1 Maximum growth rate $\mu_{\text {max }}$. The maximum growth rate $\left(\mu_{\max }\right)$ of the microbiomes was calculated during the growth phase coupled to product formation. The length of this growth phase was evaluated by visualizing the change of $\mathrm{OD}_{600} \mathrm{~nm}$ in semi-log plot over the cultivation time. A straight line with increasing slope, representing $\mu_{\max }$, was found for the period between $25 \mathrm{~h}$ to $46 \mathrm{~h}$ for the bioreactors and $20 \mathrm{~h}$ to $44 \mathrm{~h}$ for the serum bottles and the lab flasks, respectively.

2.4.2 Carbon recovery. The carbon recovery was determined as proportion of substrate carbon from ethanol, acetate and yeast extract bound in the products $n$-butyrate and $n$-caproate (eqn (3)) comparing start and end concentrations in the individual experiments.

Carbon recovery $[\%]=\left|\frac{\Delta \mathrm{C} \mathrm{mol} \text { mbutyrate }+n \text {-caproate }}{\Delta \mathrm{C} \mathrm{mol} \mathrm{m}_{\text {ethanol+acetate+yeast extract }}} \times 100 \%\right|$

with $\Delta \mathrm{C}$ mol being the amount $[\mathrm{mol}]$ of carbon bound either in the substrates (ethanol, acetate, yeast extract) or the products ( $n$ butyrate, $n$-caproate).

The potential contribution of yeast extract to the carbon recovery as indirect substrate was determined in an additional experiment. Microbiomes $(n=3)$ cultivated in DSM 52 medium without acetate and ethanol in serum bottles for $85 \mathrm{~h}$ were analyzed for the formation of substrates which could contribute to the reverse $\beta$-oxidation pathway (eqn (1) and (2)). Formate and acetate formation were observed with a maximum of $31.3 \pm$ $0.7 \mathrm{C} \mathrm{mM}$ in total and therefore included as substrate carbon.

The carbon bound in cellular biomass was calculated based on a theoretical molecular composition of cellular biomass proposed by Roels (1980) of $\mathrm{CH}_{1.8} \mathrm{O}_{0.5} \mathrm{~N}_{0.2}$ (MW $=24.6 \mathrm{~g}$ $\left.\mathrm{mol}^{-1}\right)^{20}$ and on the determined cell dry weight (for details please see Material and method section 2.3.5).

2.4.3 Medium-chain CA production rate $\boldsymbol{r}_{\mathrm{x}}$. The mediumchain CA production rate $r_{\mathrm{x}}\left[\mathrm{mmol} \mathrm{L}^{-1} \mathrm{~h}^{-1}\right]$ was determined for $n$-butyrate and $n$-caproate individually. The maximum $n$ butyrate formation rate $r_{\mathrm{C}_{4}}$, max was calculated as average of the $n$-butyrate formation rates between $28 \mathrm{~h}$ to $43 \mathrm{~h}$ for the bioreactors and between $20 \mathrm{~h}$ and $40 \mathrm{~h}$ for the serum bottles and the lab flasks, respectively. The maximum $n$-caproate formation rate $r_{\mathrm{C}_{6}}$, max was calculated as average of the $n$-caproate formation rates between $40 \mathrm{~h}$ to $52 \mathrm{~h}$ for the bioreactors and between $40 \mathrm{~h}$ and $48 \mathrm{~h}$ for the serum bottles and the lab flasks, respectively.

2.4.4 Reynolds number Re. The fermentation broth was assumed to be a Newtonian fluid. The impeller Reynolds number Re was calculated for the lab flask and the bioreactor (both with continuous agitation) according to Sinnott et al.: ${ }^{21}$

$$
\operatorname{Re}=\frac{\rho \times N \times d^{2}}{\mu_{\text {vis }}}
$$

where $\rho$ is the density of the liquid, $N$ is the rotational speed, $d$ is the diameter of the agitator and $\mu_{\text {vis }}$ is the dynamic viscosity. First the density $\rho\left(37^{\circ} \mathrm{C}\right)$ of the fermentation broth was measured with a pycnometer $\left(5 \mathrm{~cm}^{3}\right.$, Brand $\mathrm{GmbH}$, Wertheim,
Germany) and the kinetic viscosity $\nu\left(37^{\circ} \mathrm{C}\right)$ of the fermentation broth was determined by a viscometer (Micro Ostwald viscometer, Schott AG, Mainz, Germany). Secondly, the dynamic viscosity was calculated according to eqn (5).

$$
\mu_{\mathrm{vis}}=\nu \times \rho
$$

with these numbers Re was calculated according to eqn (4).

2.4.5 Statistical analysis. For characterizing differences between the scales statistical analysis was performed using a student's $t$-test of the respective results (OriginPro software (OriginLab, Northampton, USA)). In case of unequal sample numbers the Welch's $t$-test (unequal variance $t$-test) was applied for the calculation of the $p$-value. The confidence interval for both $t$-tests was $95 \%$. All values are provided as mean \pm standard deviation.

\section{Results and discussion}

First, a systematic screening of the microbiome for optimal $n$ butyrate and $n$-caproate production was conducted in serum bottles. Afterwards, upscaling from serum bottles $(110 \mathrm{~mL})$ via lab flasks $(440 \mathrm{~mL})$ to standard bioreactors $(2.2 \mathrm{~L})$ was performed to assess the transferability of the performance of the microbiome into biotechnologically more relevant reaction systems with further upscale potential.

\subsection{Screening experiments}

Screening experiments for suitable media and substrate concentrations were performed. In a first step DSM 52 medium and medium according to Zhang ${ }^{\mathbf{1 6}}$ were compared for microbial medium-chain CA formation. Cultivation in the medium according to Zhang led to a very long lag-phase of six weeks whereas medium-chain CA formation in the DSM 52 medium started within ten days. The long lag-phase in the medium according to Zhang is most likely caused by the lack of yeast extract. Yeast extract is a complex mixture of amino acids, salts and growth factors like vitamins and it was already found that higher yeast extract concentration increased medium-chain CA formation by improving protein biosynthesis. ${ }^{22,23}$ Accordingly, the DSM 52 medium containing yeast extract was used as base medium for all subsequent experiments.

A systematic screening of the microbiome for optimal $n$ butyrate and $n$-caproate production was conducted in serum bottles by using four different ethanol/acetate ratios (molar ratios of 1.32 to 4.13 ) (see Table $\mathrm{S} 2 \dagger$ ). The ethanol/acetate ratio was shifted by keeping a constant ethanol concentration of approximately $320 \mathrm{mM}$ and varying the concentration of acetate.

As Fig. 1 and Table $\mathrm{S} 2 \uparrow$ show using an ethanol/acetate ratio of 1.3, i.e. starting with $311 \mathrm{mM}$ ethanol and $235 \mathrm{mM}$ acetate, the highest final carbon recovery of $61.69 \%$ was achieved, representing also the highest $n$-butyrate and $n$-caproate concentrations of $68.3 \pm 0.2 \mathrm{mM}$ and $65.6 \pm 1.0 \mathrm{mM}$, respectively. By increasing the ethanol/acetate ratio up to 3.25 the carbon recovery decreased to $51.20 \%$ with a more selective production 


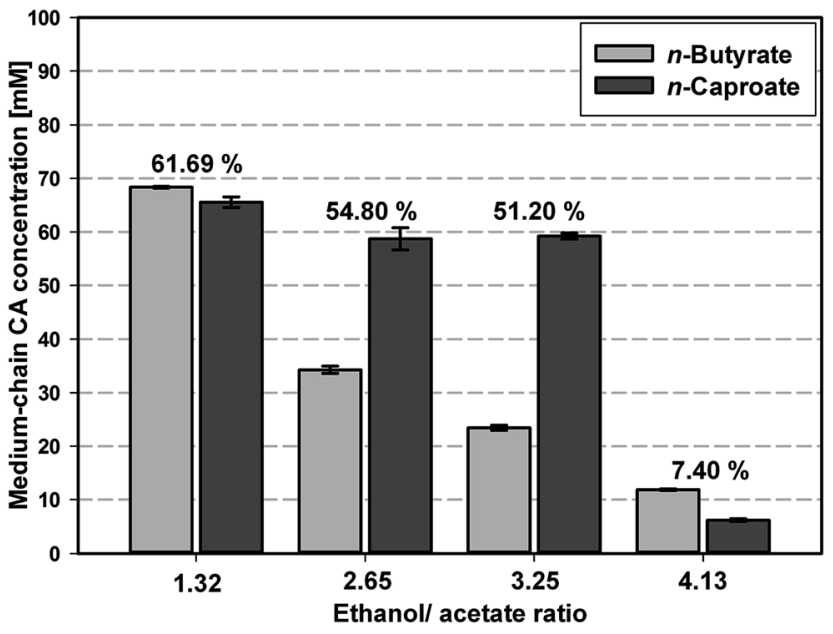

Fig. 1 Screening of microbiome-based $n$-butyrate and $n$-caproate formation depending on initial ethanol/acetate ratio in DSM 52 medium performed in serum bottles. The numbers above each pair of bars represent the calculated carbon recovery of substrate carbon into the medium-chain CA. Reported values are averages of four replicates and the error bars represent the standard deviation. For further details regarding ethanol and acetate concentrations see Table S2. $\dagger$

of $n$-caproate $(59.2 \pm 0.6 \mathrm{mM})$ than $n$-butyrate $(23.4 \pm 0.5 \mathrm{mM})$. The observed behavior of the microbiome regarding product formation at the certain ethanol/acetate ratios is in agreement with the results of earlier studies for pure cultures of C. kluyveri $^{\mathbf{1 0 , 1 2}}$ and a recently published theoretical approach. ${ }^{6}$ The application of too high ethanol concentrations of $463 \mathrm{mM}$ and $712 \mathrm{mM}$ strongly reduced medium-chain CA formation probably due to inhibition of microbial activity. ${ }^{24}$ As the aim of this study was investigating the transferability of the production performance of the microbiome, an ethanol/acetate ratio of 1.2 \pm 0.1 was used to maximize the total medium-chain CA production for the upscaling experiments.

\subsection{Functional enrichment of the microbiome}

The microbiome originating from a leach bed reactor was cultivated on serum bottle level in DSM 52 medium with a regular sub-cultivation every two weeks. This led to a functional enrichment of the microbiome over time which is reflected in an increased carbon recovery from the first transfer to the $26^{\text {th }}$ transfer (which was used for upscaling experiments, Fig. 2C and Table 2) as well as a change in the community composition (Fig. S3†). Further, methanogenic archaea, which could be major substrate competitors for acetate under the applied cultivation conditions, ${ }^{22}$ were outcompeted during this sub-cultivation procedure. While other studies required the addition of cost-intensive agents (e.g. 2bromoethanesulfonate $\left.(\mathrm{BES})^{5,25}\right)$ to inhibit methanogenesis, we did not detect any methane (calibration limit for $\mathrm{CH}_{4}$ : $0.1 \%$ ) on serum bottle level after the third transfer. This means that the applied procedure is adequate to eliminate methanogenic archaea from the microbiome to optimize the process efficiency.
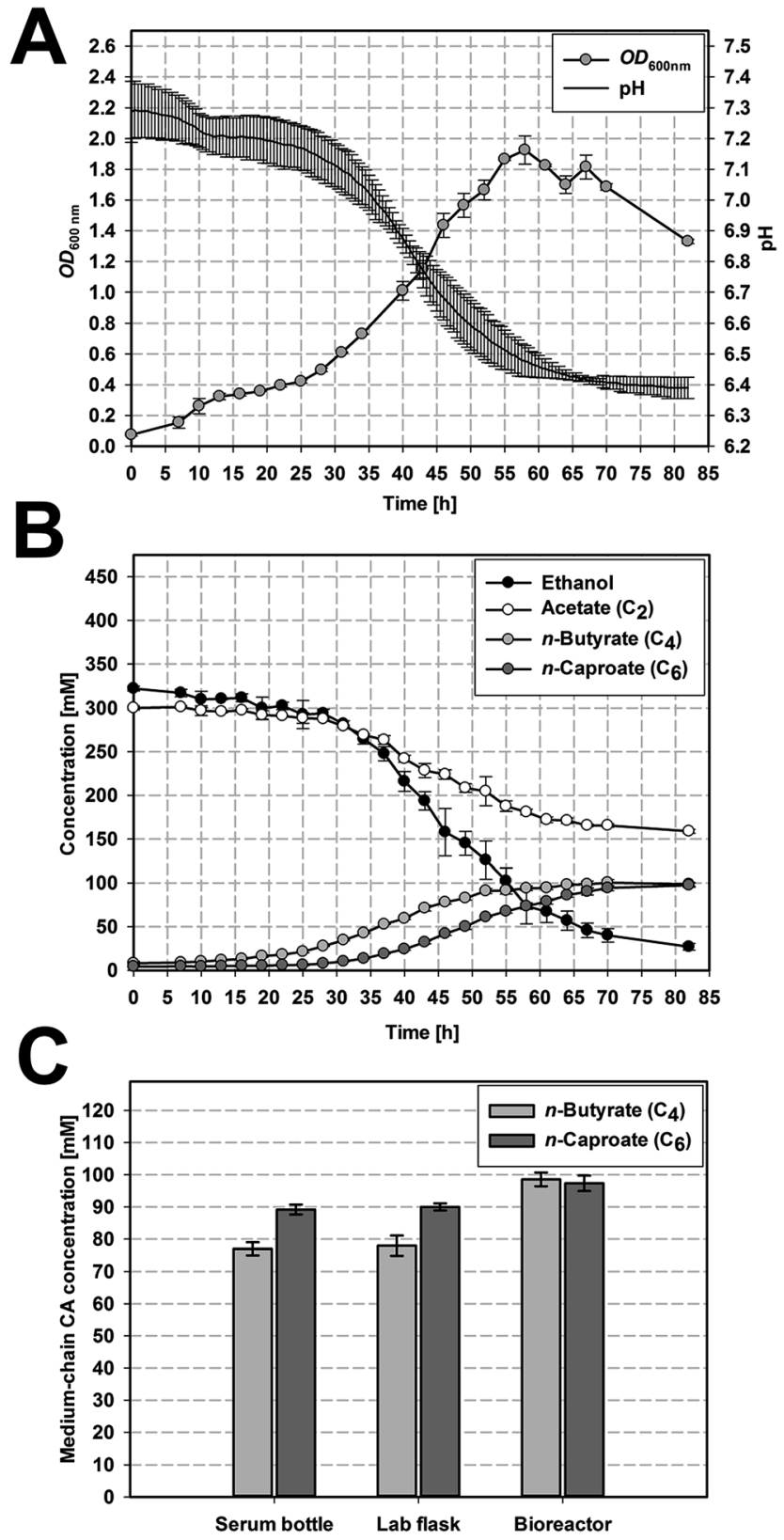

Fig. 2 Microbiome-based medium-chain CA formation from acetate and ethanol on different volumetric scales. Growth curve and $\mathrm{pH}(\mathrm{A})$ and the accordant production of $n$-butyrate and $n$-caproate (B) in standard bioreactors, reported values are averages of three replicates. (C) Final concentration of $n$-butyrate and $n$-caproate on the different volumetric scales, reported values for serum bottles $(110 \mathrm{~mL})$ and lab flasks $(440 \mathrm{~mL})$ are averages of four replicates and for bioreactors (2.2 L) of three replicates. The error bars represent the standard deviation.

\subsection{Upscaling experiments}

A high formation of $n$-butyrate and $n$-caproate was observed on all three scales ( $c f$. Fig. 2 and S1 $\dagger$ ). It started $15 \mathrm{~h}$ to $20 \mathrm{~h}$ after inoculation for $n$-butyrate and after 31 to $36 \mathrm{~h}$ for $n$-caproate ( $c f$. Fig. 2B, S2B and S2C $\dagger$ ). A significantly higher maximum $n$ butyrate production rate $r_{\mathrm{C}_{4}}$, max was found for the bioreactors $\left(2.99 \pm 0.11 \mathrm{mmol} \mathrm{L}^{-1} \mathrm{~h}^{-1}\right.$, Fig. 2B) compared to serum bottles $\left(1.94 \pm 0.05 \mathrm{mmol} \mathrm{L}^{-1} \mathrm{~h}^{-1}, p=0.006\right)$ and lab flask $(2.24 \pm$ 
$\left.0.27 \mathrm{mmol} \mathrm{L}^{-1} \mathrm{~h}^{-1}, p=0.045\right)$ which did not differ significantly $(p=0.801)$. The maximum $n$-caproate production rate $r_{\mathrm{C}_{6}, \max }$ was highest in the continuously agitated reactors $(3.10 \pm$ $0.21 \mathrm{mmol} \mathrm{L}^{-1} \mathrm{~h}^{-1}$ in the lab flask, $3.06 \pm 0.08 \mathrm{mmol} \mathrm{L}^{-1} \mathrm{~h}^{-1}$ in the bioreactor) and differed significantly from the serum bottles $\left(2.27 \pm 0.06 \mathrm{mmol} \mathrm{L}^{-1} \mathrm{~h}^{-1}, p=0.031\right)$.

Serum bottles and lab flasks reached similar final concentrations of $n$-butyrate and $n$-caproate (Table 2) resulting in similar total acid production values $(843.2 \pm 20 \mathrm{C} \mathrm{mM}$ serum bottles, $852.0 \pm 18 \mathrm{C} \mathrm{mM}$ lab flasks).

The highest total medium-chain CA concentration was reached in the bioreactors with $977.8 \pm 22.8 \mathrm{C} \mathrm{mM}$ based on significantly higher concentrations of $n$-butyrate $(98.5 \pm 2.1$ $\mathrm{mM})$ and $n$-caproate $(97.3 \pm 2.4 \mathrm{mM})$ compared to the two other scales ( $p=0.012 v s$. serum bottle and $p=0.021 v s$. lab flask). This represents an increase by factor 1.26 for $n$-butyrate and 1.12 for $n$-caproate. Furthermore, on all three scales the $\mathrm{OD}_{600}$ $\mathrm{nm}$ increased with medium-chain CA formation. This growth dependent formation of $n$-butyrate and $n$-caproate is in accordance with the assumption that microbial chain elongation of ethanol and acetate to $n$-butyrate and $n$-caproate is performed by the reverse $\beta$-oxidation pathway.

3.3.1 Headspace gas composition. On all three volumetric scales the initial headspace gas composition was $84 \% \mathrm{~N}_{2}$ and $16 \% \mathrm{CO}_{2}$. During cultivation gas production was observed. The proportion of $\mathrm{H}_{2}$ permanently increased on all three scales (Fig. S2 $\dagger$ ) which supports the proposed reverse $\beta$-oxidation pathway. In the bioreactor the $\mathrm{H}_{2}$ proportion reached $80.04 \pm$ $0.81 \%$ after $61 \mathrm{~h}$ and then slowly further increased to a final proportion of $81.59 \pm 0.11 \%$ after $82 \mathrm{~h}$. A similar increase of $\mathrm{H}_{2}$ concentration up to finally $75.64 \pm 0.76 \%$ and $76.38 \pm 0.87 \%$ for the serum bottles and the lab flasks, respectively, was measured after $85 \mathrm{~h}$. The working volume to headspace ratio (Table 2) can theoretically influence the $\mathrm{H}_{2}$ partial pressure. ${ }^{6}$ Yet, as the $\mathrm{H}_{2}$ proportion in the headspace was found to be independent from the headspace volume the $\mathrm{H}_{2}$ partial pressure was not considered to be a limiting factor in this study. Furthermore, no $\mathrm{CH}_{4}$ was detected during the whole experiment indicating the absence of methanogenic archaea as discussed above (Section 3.2). $\mathrm{CO}_{2}$ increased during cultivation up to a proportion of approximately $22 \%$ (period between $37 \mathrm{~h}$ and $49 \mathrm{~h}$ in the bioreactor) and decreased again to $12 \%$ by the end of the experiment.

3.3.2 Microbiome composition. A comparable microbial community composition and function was maintained over all scales. DNA fingerprint analysis (Fig. 3) combined with sequencing (Fig. S4†) of samples taken at the end of the experiment on each scale revealed that the microbiome was dominated by Clostridia (95\%). Microorganisms closest related to Clostridium kluyveri and Clostridium cochlearium dominated the microbial community with 32 to $42 \%$ and 38 to $45 \%$. In accordance with literature, ${ }^{9-13}$ C. kluyveri is most probably the key organism for the medium-chain CA formation in this study, as it is the only predominant organism in the microbiome for which the ability of medium-chain CA formation based on ethanol and acetate leading to the formation of $n$-butyrate and $n$-caproate (reverse $\beta$-oxidation) is described. The other Clostridia supposedly fed on the yeast extract contained in the media. For instance, C. cochlearium and C. glycolicum are described to convert amino acids and yeast extract to acetate (see Fig. S4 $\dagger$ ). ${ }^{\mathbf{2 6 , 2 7}}$ When assuming glutamic acid as a major component of yeast extract the provided amount is conceivable for growth of $C$. cochlearium $\left(\mu_{\max }=0.36 \mathrm{~h}^{-1}\right.$, half velocity constant $K_{\mathrm{S}}$ of only $\left.7 \mu \mathrm{M}\right)^{28}$ and could explain its detection as major contributor to the microbiome. The potential contribution of fermentation products based on the yeast extract was considered for the carbon recovery (for details see Material and methods section 2.4.2).

3.3.3 Carbon recovery. Considering the carbon recovery from substrates converted into medium-chain CA values of $94.06 \pm 7.74 \%$ in the serum bottles, $90.40 \pm 5.67 \%$ in the lab flasks and $92.87 \pm 5.66 \%$ in the bioreactors were obtained. This indicates a highly effective conversion of ethanol and acetate into $n$-butyrate and $n$-caproate, although other reactions of the

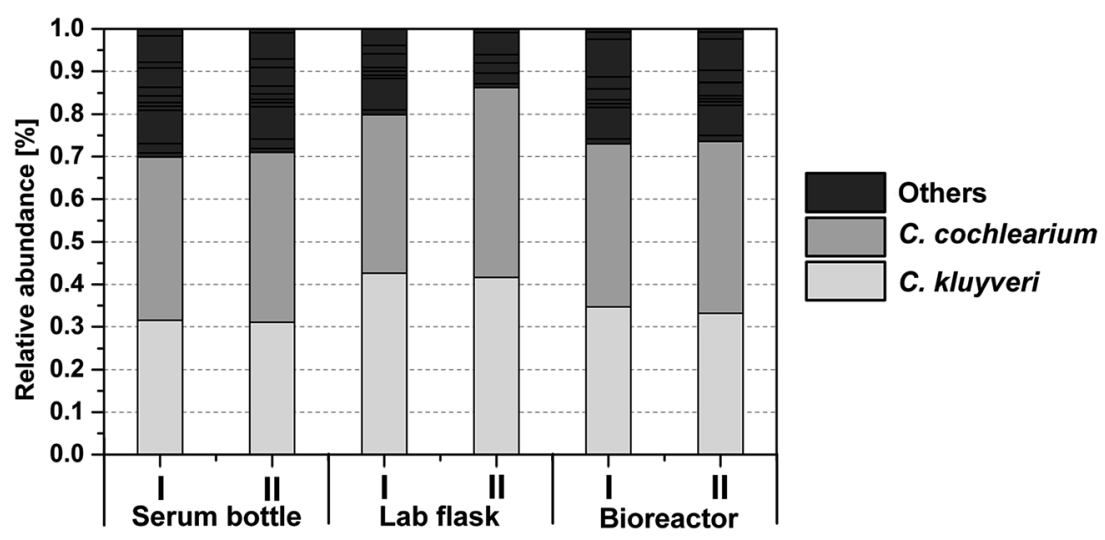

Fig. 3 Community composition based on the DNA fingerprinting technique T-RFLP. The bars represent the major terminal restriction fragments (tRFs) after restriction digestion with Haelll in two out of three (standard bioreactor, see Table 2) or four (serum bottle and lab flask, see Table 2) biological replicates of each scale at the end of the fermentation $(85 \mathrm{~h}$ for serum bottle and lab flask and $82 \mathrm{~h}$ for the standard bioreactor, see Table 2). The grey scale in the legend represents the different tRFs with the corresponding tRFs of $C$. kluyveri and $C$. cochlearium being identified by T-RFLP of the corresponding single clones after sequencing. 
microbiome than reverse $\beta$-oxidation might contribute to the overall carbon balance, e.g. based on $\mathrm{CO}_{2}$ fixation ${ }^{23}$ or yeast extract oxidation. The potential contribution of these side reactions was estimated in a control experiment. Microbiomes cultivated without acetate and ethanol, thus having only $\mathrm{CO}_{2}$, bicarbonate and yeast extract as potential carbon sources, produced $31.3 \pm 0.7 \mathrm{C} \mathrm{mM}$ in the form of formate $\left(\mathrm{C}_{1}\right)$ and acetate. No ethanol was detected. This meets the theoretical value of carbon available from the added yeast extract (33.14 C$\mathrm{mM}$ ) although a partial utilization of $\mathrm{CO}_{2} / \mathrm{HCO}_{3}{ }^{-}$cannot be excluded. Nevertheless, we consider $\mathrm{CO}_{2}$ fixation more relevant for biomass formation than for the release of alternative substrates (e.g. less than $2 \%$ of the $\mathrm{CO}_{2}$ fixed by C. kluyveri is converted into acetate ${ }^{29}$ while a minimum of $70 \%$ is recovered in cellular biomass $\left.{ }^{30}\right)$. The total biomass formation was found to represent only a small carbon sink (17.3 C mM, i.e. 0.426 $\mathrm{g}_{\mathrm{CDW}} \mathrm{L}^{-1}$, is bound in cellular biomass representing $2.2 \%$ of the converted carbon) compared to the overall carbon turnover. Therewith, the carbon recovery of the microbiome is comparable to the pure culture based fermentation with $C$. kluyveri at a similar ethanol/acetate ratio ${ }^{31}$ and additionally provides the already introduced advantages of microbiome based fermentation (no need for sterilization, potential applicability to complex feedstocks).

\subsection{Implications for application}

The microbiome composition was independent from the reactor scale. Consequently, a high and reproducible carbon recovery as well as a similar, but not identical, time course of cultivation (Fig. 2B and $\mathrm{S} 1 \dagger$ ) was observed. While the carbon recovery is not influenced by the reactor scale and the agitation regime (carbon recovery from $90.40 \pm 5.67 \%$ to $94.06 \pm 7.74 \%$ across the scales), the final medium-chain CA concentration seems to be influenced. Introducing agitation increases $r_{\mathrm{C}_{4} \text {, max }}$ and $r_{\mathrm{C}_{6} \text {,max }}$ in the lab flask and the bioreactor (Table 2) compared to the serum bottles without agitation. In accordance with these results, $\mu_{\max }$ increased in the agitated vessels compared to the serum bottles. The difference in performance $\left(r_{\mathrm{C}_{4}, \text { max }}, r_{\mathrm{C}_{6}, \text { max }}\right.$ and $\left.\mu_{\text {max }}\right)$ between shaking once a day in the serum bottle and constantly mixing in the lab flask is not statistically significant although a flow regime in the lab flask, as expressed by the Reynolds number of $3.8 \times 10^{3}$, close to transitional flow $\left(10^{2}<\operatorname{Re}<10^{3}\right)^{32}$ was implemented. However, the most turbulent flow regime, i.e. close to full turbulent flow in stirred tank reactors $\left(\mathrm{Re}>10^{4}\right),{ }^{32}$ applied in the bioreactor ( $\mathrm{Re}$ $=9.4 \times 10^{3}$ ) led to significantly higher $\mu_{\max }, r_{\mathrm{C}_{4} \text {, max }}$ and $r_{\mathrm{C}_{6} \text {, max }}$ and finally to a significantly higher product titer. In this way, agitation was identified as a potential key parameter for further upscaling as an increase of the mass transfer coefficient by increasing the power input for mixing improved the performance of the overall process. A further increase of the agitation will be a matter of subject in future studies. Nevertheless a higher power input has to be considered for the economic feasibility of the overall process. ${ }^{33}$

In this study, $n$-butyrate and $n$-caproate formation stagnate at concentrations of $98.5 \pm 2.1 \mathrm{mM}$ and $97.3 \pm 2.4 \mathrm{mM}$ in the bioreactor probably due to end-product inhibition. For a biotechnological production platform a continuous mediumchain CA formation should be aimed at and would be the next step for process optimization. With the current cultivation conditions the $\mathrm{pH}$ drops with medium-chain CA accumulation. The closer the $\mathrm{pH}$ is to the $\mathrm{p} K_{\mathrm{a}}$ value of the acids, the higher is the concentration of the undissociated form of the mediumchain CA. These uncharged molecules then can easily pass the cell membrane ${ }^{\mathbf{1 4}}$ leading to acidification of the cytoplasm due to dissociation, as the cytoplasmic $\mathrm{pH}$ is above the $\mathrm{p} K_{\mathrm{a}}{ }^{34}$ and thereby may have cytotoxic effects on energy metabolism and cell growth. ${ }^{35}$ Also the anion itself can be cytotoxic as its hydrophilic interaction potentially affects essential pathways. ${ }^{36-38}$ When assuming ideal conditions and using the Henderson-Hasselbalch equation the final concentrations of undissociated $n$-butyrate (n-butyric acid) and $n$-caproate ( $n$-caproic acid) in the bioreactor can be estimated to be $3.3 \mathrm{mM}$ $n$-butyric acid and 3.0 mM $n$-caproic acid. End-product inhibition was reported to start at higher concentrations of undissociated $n$-butyrate $\left(10.8 \mathrm{mM}^{39} 48 \mathrm{mM}^{40}\right)$ or $n$-caproate $\left(7.5 \mathrm{mM}^{6}\right)$ in other microbiome studies. A reason why the highest agitation led to higher final product titers could also be that improved mixing reduced the medium-chain CA concentration in close vicinity to the cells compared to the bulk medium. However, the microbiome investigated in this study might become less susceptible to medium-chain CA inhibition after continuous cultivation or fed-batch cultivation, with increased exposure time to medium-chain CA. Alternative limitations like availability of trace elements, vitamins, yeast extract, substrates (ethanol or acetate individually and as mixture) were tested by addition of these components to the medium after stagnation of substrate consumption and medium-chain CA formation, but did not result in further growth or product formation (data not shown). These findings support the hypothesis that endproduct inhibition is the major process limitation.

When comparing the results of this microbiome-based medium-chain CA formation to other studies using acetate and ethanol (Table 1) its high potential as a biotechnological production platform becomes evident. In comparison with all studies from Table 1 the highest total medium-chain CA concentration of $977.8 \pm 22.8 \mathrm{C} \mathrm{mM}$ was reached in our experiments on $2.2 \mathrm{~L}$ standard bioreactor scale - after previous screening for the optimal cultivation conditions on serum bottle level.

In contrast to other microbiome-based studies, ,22,41,42 however, caprylate $\left(\mathrm{C}_{8}\right)$ formation was not observed (Fig. S5 $\dagger$ ). Reasons for this could be differences in the cultivation conditions (e.g. continuous cultivation and $\mathrm{pH}$ control $^{5}$ ) or a general limitation in the metabolic potential of the microbiome. Steinbusch et al. (2011) ${ }^{5}$ and Zhang et al. (2013) ${ }^{16}$ suggested $\mathrm{H}_{2}$ as additional alternative electron donor for caprylate formation in microbiome-based medium-chain CA formation. A continuous increase of $\mathrm{H}_{2}$ in the headspace gas was found in our experiments but was obviously not utilized. Therefore, a general metabolic restriction of the C. kluyveri strain in our experiments is most likely ${ }^{26}$ and was also confirmed in long-term incubations up to 18 months (data not shown). Our result is in accordance with other 
studies, ${ }^{\mathbf{4 3 4 4}}$ while other microbiomes showing $\mathrm{C}_{8}$ formation might have contained other strains ${ }^{5,22,41}$ or no C. kluyveri at all. ${ }^{42}$

\section{Conclusion}

We have investigated the predictability and transferability of microbiome-based medium-chain CA formation across scales from the simple serum bottle cultivation up to cultivation in standard bioreactors. The stable microbiome composition established by serum bottle cultivation was the basis for the transferability of the microbiome performance and the upscaling of the whole process to standard bioreactors $(2.2 \mathrm{~L})$. Hence, small scale cultivation on serum bottle level was demonstrated to serve as a time and resource efficient approach for targeted screening of suitable cultivation conditions and microbiome adaptation. The described experimental approach can be transferred to microbiomes exploiting complex feedstocks and producing platform chemicals by anaerobic fermentation. Introducing agitation enhanced the product formation rates $r_{\mathrm{C}_{4} \text {, max }}$ and $r_{\mathrm{C}_{6} \text {, max }}$ and should be considered as a key parameter for further upscaling. It yielded maximum total medium-chain CA concentration of $977.8 \pm 22.8 \mathrm{C} \mathrm{mM}$ with competitively high $n$-butyrate $(98.5 \pm 2.1 \mathrm{mM})$ and $n$-caproate $(97.3 \pm 2.4 \mathrm{mM})$ concentrations from acetate and ethanol at a carbon recovery close to $95 \%$ and was only restricted by endproduct inhibition. This can be circumvented in future, e.g. by (1) in-line extraction in a single-phase fermentation system at low $\mathrm{pH},{ }^{45}$ or by (2) two-phase fermentation systems at a neutral $\mathrm{pH}$ to achieve a continuous process. ${ }^{46}$ After extraction, the direct use of the CA is limited. For instance $n$-caproate can be used as animal feed and green antimicrobial substance. ${ }^{45}$ The utilization of CA as biofuels is not possible, due to their high oxygento-carbon ratio and their low energy density. For this reason, they have to be further converted to liquid biofuels like energydense alkanes and esters. This can already be realized by electroorganic synthesis, e.g. Kolbe and non-Kolbe electrolysis, ${ }^{\mathbf{4 7 , 4 8}}$ thus expanding the application potential for medium-chain CA production as valuable platform for chemical and biofuel production.

\section{Acknowledgements}

We thank Anne Kuchenbuch and Desiree Schmidt for very valuable technical assistance in molecular biology. Furthermore we thank Dr Claus Härtig and Angelika Wichmann for GC-MS measurements. Further we thank Dr Jana Mühlenberg for CHNS analysis. F. H. acknowledges support by the BMBF (Research Award "Next generation biotechnological processes Biotechnology 2020+") and the Helmholtz-Association (Young Investigators Group). This work was supported by the Helmholtz-Association within the Research Programme Renewable Energies. There is no conflict of interests.

\section{References}

1 R. Kleerebezem and M. C. M. van Loosdrecht, Curr. Opin. Biotechnol., 2007, 18(3), 207.
2 M. T. Agler, B. A. Wrenn, S. H. Zinder and L. T. Angenent, Trends Biotechnol., 2011, 29(2), 70.

3 P. Weiland, Appl. Microbiol. Biotechnol., 2010, 85(4), 849.

4 C. M. Spirito, H. Richter, K. Rabaey, A. J. M. Stams and L. T. Angenent, Curr. Opin. Biotechnol., 2014, 27, 115.

5 K. J. J. Steinbusch, H. V. M. Hamelers, C. M. Plugge and C. J. N. Buisman, Energy Environ. Sci., 2011, 4(1), 216.

6 L. T. Angenent, H. Richter, W. Buckel, C. M. Spirito, K. J. J. Steinbusch, C. M. Plugge, D. P. B. T. B. Strik, T. I. M. Grootscholten, C. J. N. Buisman and H. V. M. Hamelers, Environ. Sci. Technol., 2016, 50(6), 2796.

7 C. Koch, S. Müller, H. Harms and F. Harnisch, Curr. Opin. Biotechnol., 2014, 27, 65.

8 C. W. Marshall, E. V. LaBelle and H. D. May, Curr. Opin. Biotechnol., 2013, 24(3), 391.

9 H. A. Barker and S. M. Taha, J. Bacteriol., 1942, 43(3), 347.

10 B. T. Bornstein and H. A. Barker, J. Biol. Chem., 1948, 172, 659.

11 W. R. Kenealy, Y. Cao and P. J. Weimer, Appl. Microbiol. Biotechnol., 1995, 44(3-4), 507.

12 G. M. Smith, B. W. Kim, A. A. Franke and J. D. Roberts, J. Biol. Chem., 1985, 260(25), 13509.

13 P. J. Weimer and D. M. Stevenson, Appl. Microbiol. Biotechnol., 2012, 94(2), 461.

14 K. Choi, B. S. Jeon, B. C. Kim, M. K. Oh, Y. Um and B. I. Sang, Appl. Biochem. Biotechnol., 2013, 171(5), 1094.

15 H. Sträuber, R. Lucas and S. Kleinsteuber, Appl. Microbiol. Biotechnol., 2016, 100(1), 479.

16 F. Zhang, J. Ding, Y. Zhang, M. Chen, Z. W. Ding, M. C. M. van Loosdrecht and R. J. Zeng, Water Res., 2013, 47(16), 6122.

17 C. Koch, D. Popiel and F. Harnisch, ChemElectroChem, 2014, 1(11), 1923.

18 Q. Wang, G. M. Garrity, J. M. Tiedje and J. R. Cole, Appl. Environ. Microbiol., 2007, 73(16), 5261.

19 S. McGinnis and T. L. Madden, Nucleic Acids Res., 2004, 32, W20-W25.

20 J. A. Roels, Biotechnol. Bioeng., 1980, 22(12), 2457.

21 R. K. Sinnott, J. M. Coulson and J. F. Richardson, Chemical engineering design, Elsevier Butterworth-Heinemann Amsterdam, Amsterdam, 2006.

22 T. I. M. Grootscholten, K. J. J. Steinbusch, H. V. M. Hamelers and C. J. N. Buisman, Bioresour. Technol., 2013, 135, 440.

23 M. E. Martin, H. Richter, S. Saha and L. T. Angenent, Biotechnol. Bioeng., 2016, 113(3), 531.

24 S. Lonkar, Z. Fu and M. Holtzapple, Biotechnol. Bioeng., 2016, 113, 2597.

25 M. T. Agler, C. M. Spirito, J. G. Usack, J. J. Werner and L. T. Angenent, Water Sci. Technol., 2014, 69(1), 62.

26 W. B. Whitman, Bergey's Manualß of Systematic Bacteriology: Volume Three The Firmicutes, Springer-Verlag New York, New York, NY, 2009.

27 G. C. Mead, J. Gen. Microbiol., 1971, 67(1), 47.

28 H. J. Nanninga, W. J. Drent and J. C. Gottschal, FEMS Microbiol. Lett., 1986, 38(6), 321.

29 N. Tomlinson and H. A. Barker, J. Biol. Chem., 1954, 209(2), 585. 
30 B. T. Bornstein and H. A. Barker, J. Bacteriol., 1948, 55(2), 223.

31 H. A. Barker, Antonie van Leeuwenhoek, 1947, 12(1-4), 167.

32 J. M. Smith, Chemical engineering kinetics, McGraw-Hill Inc., New York, N.Y., 1981.

33 M. P. C. Marques, J. M. S. Cabral and P. Fernandes, J. Chem. Technol. Biotechnol., 2010, 85(9), 1184.

34 J. Zigová and E. Šturdík, J. Ind. Microbiol. Biotechnol., 2000, 24(3), 153.

35 P. J. Henderson, Annu. Rev. Microbiol., 1971, 25, 393.

36 J. B. Russell and F. Diez-Gonzalez, Adv. Microb. Physiol., 1998, 39, 205.

37 S. Stolte, J. Arning, U. Bottin-Weber, M. Matzke, F. Stock, K. Thiele, M. Uerdingen, U. Welz-Biermann, B. Jastorff and J. Ranke, Green Chem., 2006, 8(7), 621.

38 A. J. Roe, C. O'Byrne, D. McLaggan and I. R. Booth, Microbiology, 2002, 148(7), 2215.

39 H. Richter, N. Qureshi, S. Heger, B. Dien, M. A. Cotta and L. T. Angenent, Biotechnol. Bioeng., 2012, 109(4), 913.
40 J. C. van den Heuvel, P. G. Verschuren, H. H. Beeftink and D. de Beer, Biotechnol. Tech., 1992, 6(1), 33.

41 T. I. M. Grootscholten, K. J. J. Steinbusch, H. V. M. Hamelers and C. J. N. Buisman, Bioresour. Technol., 2013, 136, 735.

42 L. A. Kucek, C. M. Spirito and L. T. Angenent, Energy Environ. Sci., 2016, 9(11), 3482.

43 P. J. Weimer, M. Nerdahl and D. J. Brandl, Bioresour. Technol., 2014, 175, 97.

44 M. Coma, R. Vilchez-Vargas, H. Roume, R. Jauregui, D. H. Pieper and K. Rabaey, Environ. Sci. Technol., 2016, 50(12), 6467.

45 M. T. Agler, C. M. Spirito, J. G. Usack, J. J. Werner and L. T. Angenent, Energy Environ. Sci., 2012, 5(8), 8189.

46 T. I. M. Grootscholten, D. P. B. T. B. Strik, K. J. J. Steinbusch, C. J. N. Buisman and H. V. M. Hamelers, Appl. Energy, 2014, 116, 223.

47 C. Stang and F. Harnisch, ChemSusChem, 2016, 9(1), 50.

48 P. F. Levy, J. E. Sanderson, R. G. Kispert and D. L. Wise, Enzyme Microb. Technol., 1981, 3(3), 207. 